Original Articles

\title{
Use of stable isotope ratios of fish larvae as indicators to assess diets and patterns of anthropogenic nitrogen pollution in estuarine ecosystems
}

\author{
Alexandra Baeta ${ }^{\mathrm{a}, *}$, Luís Russo Vieira ${ }^{\mathrm{b}, \mathrm{c}}$, Ana Virgínia Lírio ${ }^{\mathrm{d}}$, Cristina Canhoto ${ }^{\mathrm{d}}$, João C. Marques ${ }^{\mathrm{a}}$, \\ Lúcia Guilhermino ${ }^{\mathrm{b}, \mathrm{c}}$

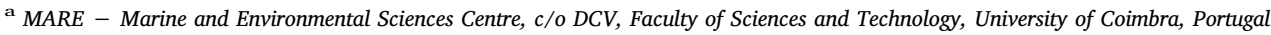 \\ b ICBAS - Institute of Biomedical Sciences of Abel Salazar, University of Porto, Department of Populations Study, Laboratory of Ecotoxicology, Rua de Jorge Viterbo \\ Ferreira n. ${ }^{\circ}$ 228, 4050-313, 4099-003 Porto, Portugal \\ c CIIMAR - Interdisciplinary Centre of Marine and Environmental Research, Research Group of Ecotoxicology, Stress Ecology and Environmental Health, University of \\ Porto, Terminal de Cruzeiros do Porto de Leixões, Av. General Norton de Matos s/n, 4450-208 Matosinhos, Portugal \\ d Centre for Functional Ecology, Department of Life Sciences, University of Coimbra, Calçada Martim de Freitas, 3000-456 Coimbra, Portugal
}

\section{A R T I C L E I N F O}

\section{Keywords:}

Pomatoschistus microps larvae

Fish larvae

Plankton

Stable isotopes

$\delta^{15} \mathrm{~N}$

$\delta^{13} \mathrm{C}$

Trophic interations

Minho and Lima estuaries

Temporal changes

Bioindicator

Nitrogen pollution

\begin{abstract}
A B S T R A C T
A stable isotope study was carried out to investigate the feeding ecology of the common goby Pomatoschistus microps larvae (Krøyer, 1838), and to assess differences in the response of planktonic food web to nutrient enrichment, in two ecosystems from the Southern European coast with different levels of historical pollution (estuaries of the Minho and Lima Rivers). At each estuary and time (July 2012, November 2012, February 2013, and June 2013), the fish larvae of two size classes (class 0: 0-10 mm; class 1: 10-15 mm), particulate organic matter (POM), and pelagic zooplankton were collected. The stable isotope mixing model SIAR revealed that, despite temporal differences in the relative proportion of prey items ingested, in both estuaries $P$. microps larvae feed on both planktonic-hyperbenthic food sources, predating mainly on copepods (from 34\% to $60 \%$ ), Mysidacea (from 16\% to 28\%), and brachyuran zoea (from 14\% to 29\%). Fish larvae size classes did not differ significantly for $\delta^{15} \mathrm{~N}$, and exhibited a very narrow range of the $\delta^{13} \mathrm{C}$ signature. Enriched $\delta^{15} \mathrm{~N}$ values of all biota in the Lima estuary throughout the study period, with a marked nitrogen enrichment in colder months, are indicative of higher anthropogenic inputs of nitrogen (e.g. sewage and industrial discharges, agriculture) into this system. The $\delta^{15} \mathrm{~N}$ values of fish larvae and other planktonic groups can be a sensitive bioindicator, because they are highly correlated with the nitrogen content of water (ammonium), indicating that this element has transferred through the planktonic food web. Enriched carbon isotope ratios were observed in warmer months, in both estuaries, and the heavier $\delta^{13} \mathrm{C}$ values in Lima are best explained by differences in the degree of marine influence. This research emphasises the utility of stable isotopes in trophic interactions studies, highlighting the relevance of the stable nitrogen isotope of zooplanktonic communities as a reliable bioindicator to detect patterns of anthropogenic nitrogen contamination in estuarine ecosystems.
\end{abstract}

\section{Introduction}

Stable isotopes of carbon and nitrogen have become a widely used tool for examining food webs, namely dietary patterns, trophic structure and nutrient transfers, across diverse ecosystems (DeNiro and Epstein, 1978, 1981; Eggers and Jones, 2000; West et al., 2006; Layman et al., 2012). In trophic interactions, as one species feeds on another one, the consumer tends to be isotopically heavier than its food source, a process called fractionation factor or trophic enrichment $\left(\Delta^{13} \mathrm{C}\right.$ and $\Delta^{15} \mathrm{~N}$ for carbon and nitrogen, respectively) (Caut et al., 2009). This effect is more pronounced in nitrogen and leads to increases in $\delta^{15} \mathrm{~N}$ of approximately 3-4\%o (Wada et al., 1991; Post, 2002) at each trophic level. Furthermore, high levels of $\delta^{15} \mathrm{~N}$ in basal sources can be used as an alternative method to establish the level of human eutrophication since anthropogenic sources of nitrogen are generally enriched in the heavy isotope when compared to natural sources (Cole et al., 2006; Bannon and Roman, 2008; Baeta et al., 2009a,b). Ratios of carbon isotopes $\left(\delta^{13} \mathrm{C}\right)$ vary substantially among primary producers with different photosynthetic pathways, but change little with trophic transfers, generally from 1 to $2 \%$ from prey to predator (Peterson and Fry, 1987; Post, 2002). Therefore, $\delta^{13} \mathrm{C}$ are typically used to determine which primary producer components are the ultimate carbon source

\footnotetext{
* Corresponding author.

E-mail address: asbaeta@ci.uc.pt (A. Baeta).
} 
Minho Estuary

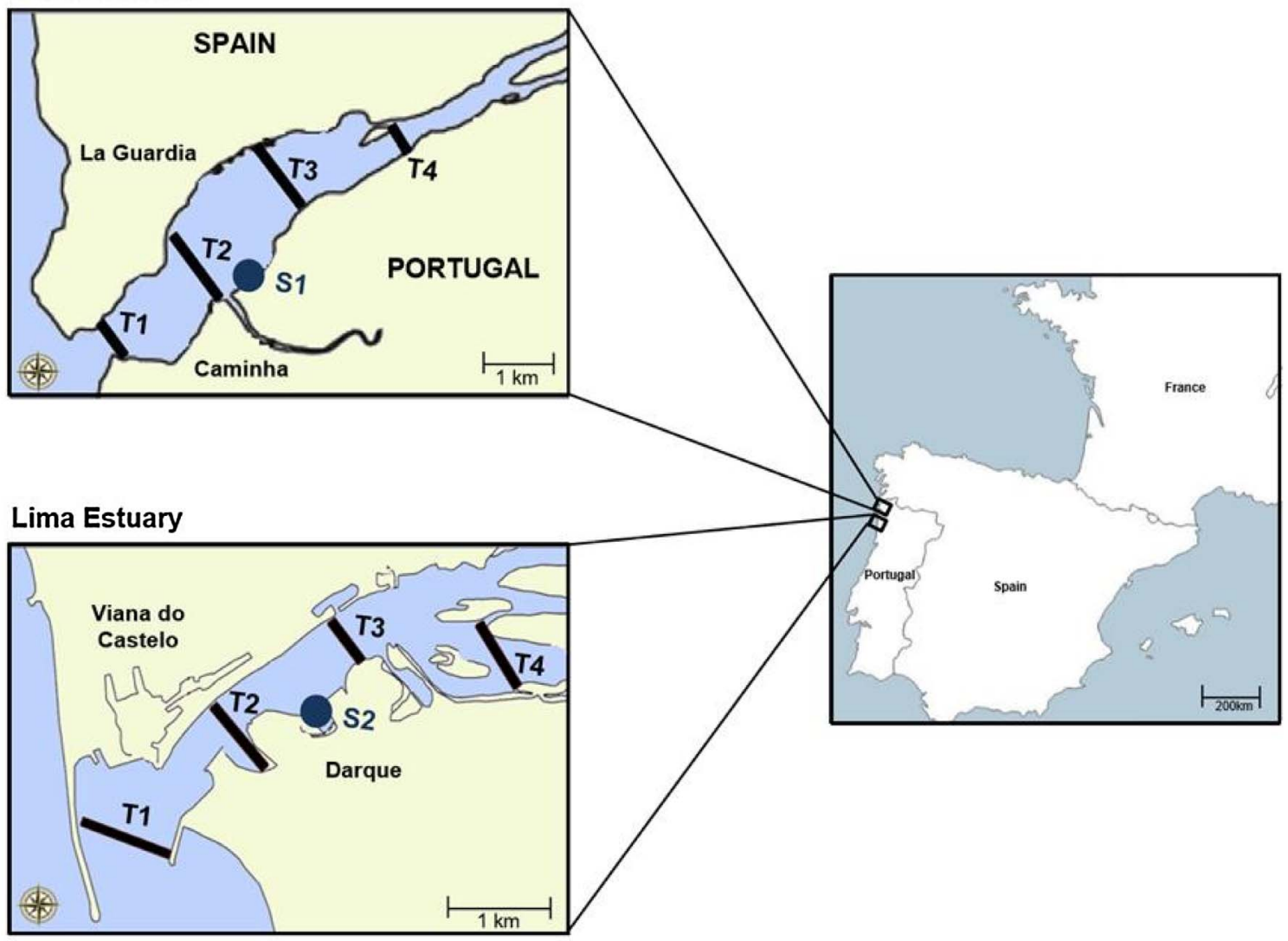

\begin{tabular}{llcccc}
\cline { 3 - 5 } & & \multicolumn{4}{c}{ Transect } \\
\cline { 3 - 5 } & & $\mathrm{T} 1$ & $\mathrm{~T} 2$ & $\mathrm{~T} 3$ & $\mathrm{~T} 4$ \\
\hline Minho & \multirow{2}{*}{ Coordinates } & $41^{\circ} 52^{\prime} 12.76^{\prime \prime} \mathrm{N}$ & $41^{\circ} 52^{\prime} 52.96^{\prime \prime} \mathrm{N}$ & $41^{\circ} 53^{\prime} 39.14^{\prime \prime} \mathrm{N}$ & $4^{\circ} 54^{\prime} 17.27^{\prime \prime} \mathrm{N}$ \\
& & $8^{\circ} 51^{\prime} 32.08 \mathrm{~W}$ & $8^{\circ} 50^{\prime} 46.14^{\prime \prime} \mathrm{W}$ & $8^{\circ} 49^{\prime} 58.61^{\prime \prime} \mathrm{W}$ & $8^{\circ} 49^{\prime} 1.66^{\prime \prime}$ \\
& & $5.16 \pm 0.73$ & $3.99 \pm 1.02$ & $2.98 \pm 1.5$ & $3.35 \pm 0.97$ \\
\hline Lima & \multirow{2}{*}{ Coordinates } & $41^{\circ} 40^{\prime} 52.25^{\prime \prime} \mathrm{N}$ & $41^{\circ} 41^{\prime} 15.05^{\prime \prime} \mathrm{N}$ & $41^{\circ} 41^{\prime} 30.88^{\prime \prime} \mathrm{N}$ & $41^{\circ} 41^{\prime} 29.14^{\prime \prime} \mathrm{N}$ \\
& & $8^{\circ} 50^{\prime} 26.21^{\prime \prime} \mathrm{W}$ & $8^{\circ} 49^{\prime} 36.42^{\prime \prime} \mathrm{W}$ & $8^{\circ} 48^{\prime} 53.63^{\prime \prime} \mathrm{W}$ & $8^{\circ} 47^{\prime} 40.91^{\prime \prime} \mathrm{W}$ \\
& & $8.55 \pm 2.37$ & $7.65 \pm 2.39$ & $5.65 \pm 1.14$ & $3.74 \pm 0.99$ \\
\hline
\end{tabular}

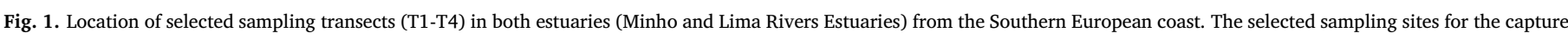
of zooplanktivorous fish are also indicated in the figure (S1-S2). The transect coordinates and average depths are presented in the table.

assimilated by higher trophic level consumers (Fry and Sherr, 1984; Peterson and Fry, 1987).

Estuarine ecosystems constitute transition zones where freshwater from land drainage and river basins mixes with seawater, creating some of the most biologically productive areas on Earth (Levin et al., 2001). Such environments are effective nurseries for several marine fish species, and provide shelter and food for several other resident ones that complete their entire life cycle within the estuarine system (Dolbeth et al., 2007, 2008). Resident species are quite relevant in estuarine food webs as intermediate predators, being consumers of plankton and benthos, and prey of several larger fishes, decapods, and birds, playing a crucial role in the overall dynamics and functioning of the estuarine ecosystem. The feeding ecology of fish larvae has been studied extensively in marine environments, whereas there are only a few studies on estuarine fish larvae worldwide, and most are completely concentrated in low-middle latitudes $\left(15-30^{\circ} \mathrm{N} / \mathrm{S}\right)$ (Llopiz, 2013), and this is somehow surprising given the levels of productivity in estuaries and the trophic role of fish larvae in the estuarine food web. Predatory success in estuarine nursery areas by fish larvae is crucial for good body condition, growth rate and ultimately for larval survival (Strydom et al., 2014). Fish larvae are typically zooplanktivorous, feeding on a variety of micro- and meso-zooplankton, often dominated by copepods, with a shift from smaller to larger prey through larval ontogeny (Llopiz, 2013). The common goby Pomatoschistus microps (Krøyer, 1838) is among the most abundant species in estuaries, lagoons and along the shores of Europe, and despite its high abundance and importance in estuarine trophic webs (Maes et al., 2003; Parmanne and Lindstrom, 2003; Salgado et al., 2004; Leitão et al., 2006; Dolbeth et al., 2008), to the best of our knowledge, only one study, Thiel et al. (1996), based on gut content analysis, has examined the diet of $P$. microps larvae.

The planktonic larval phase of fishes is characterised by high recruitment variability and mortality, and its maintenance is greatly 
determined by environmental quality conditions, such as combinations of temperature and salinity, prey availability, foraging success, and extension of nursery areas (Robert et al., 2014; Jackson and Lenz, 2016). Nevertheless, changes in these conditions are quite usual in estuaries due to natural and anthropogenic induced variations. In fact, these ecosystems are increasingly threatened by anthropogenic activities in the coastal zone and in surrounding catchments, such as application of fertilizers, discharge of human and industrial waste, animal production, and fossil fuel combustion, increasing the flux and rate of delivery of terrestrial nutrients to these environments. This increase availability of nutrients, mainly nitrogen, decreases water quality and strongly impact aquatic ecosystems (Cloern, 2001; Lotze et al., 2006).

The use of estuarine biological indicators (also called bioindicators), defined as species, populations, or communities that can be used to assess the effects of a stressors on an ecosystem, representing the cumulative effects of exposure to ecosystem-wide disturbance (Adams, 2005; Savage, 2009), might be an added value and an ideal tool to assess the impact of anthropogenic nutrient inputs on the environment before damages reaches higher trophic levels. In addition, a good bioindicator species is common in a variety of environments, enabling it to be used in estimation of ecosystem health in various instances (Nikinmaa, 2014). Typical bioindicators that have been used to assess water quality and ecosystem function include bacterial and phytoplankton community composition (Paerl et al., 2003a,b), and stable isotope ratios of macroalgae (Raimonet et al., 2013), bivalves (Graniero et al., 2016), benthic deposit-feeders (Van Dover et al., 1992), and fish (Pruell and Taplin, 2015), among others. Because of their short generation times (typically weeks to months), most planktonic organisms are considered to be excellent bioindicators of global change as they respond quickly to shifts in the aquatic environment where they occur. Accordingly, these consumers with nitrogen turnover rates on the scale of weeks to a few months provide nitrogen isotopic signatures that are sufficiently stable to reduce short-term noise but which respond quickly enough to detect anthropogenic nitrogen inputs to estuaries (Hoffman et al., 2012). Hoffman et al. (2012) was the only study found in the literature that examined nitrogen isotope signatures among fish larvae, a novel biotic indicator of anthropogenic nutrient inputs to coast receiving waters. Fish had a stable isotope response to changes in sources and their nitrogen isotopic signal has been shown to reflect nitrogen sources.

Our main objectives in this study were (1) to examine the temporal variation in the feeding ecology of $P$. microps larvae, in two estuarine ecosystems, by comparing the isotopic composition $\left(\delta^{13} \mathrm{C}\right.$ and $\left.\delta^{15} \mathrm{~N}\right)$ of possible food sources and consumers; Bayesian mixing models allowed estimation of the proportion of sources contributing to the consumers' diet; and (2) to evaluate the use of stable nitrogen isotope of fish larvae as a biological indicator to detect inputs of anthropogenic nitrogen into systems with different levels of historical pollution.

\section{Material and methods}

\subsection{Study area}

The study was carried out on two estuaries, the Minho and the Lima, located on the Southern European coast, in the northwest of Portugal (Fig. 1). The Minho River rises in Sierra de Meira, Spain and, after a course of $300 \mathrm{~km}$ reaches the sea, and in the last $77 \mathrm{~km}$ marks the border between Portugal and Spain. Its basin has a total area of approximately $17,081 \mathrm{~km}^{2}$, including $850 \mathrm{~km}^{2}$ in Portugal. The Minho estuary (hereafter designated as Minho) is very shallow, with only $9 \%$ of intertidal areas and a mean depth of $2.6 \mathrm{~m}$ (Freitas et al., 2009), and it is characterised as a mesotidal and partially mixed system, with a mean tidal range of $2 \mathrm{~m}$ and an average residence time of 1.5 days (Ferreira et al., 2005), although during periods of high river flow (annual average discharge of $300 \mathrm{~m} / \mathrm{s}$ ) it tends towards a salt wedge estuary (Sousa et al., 2005, 2014). Salt intrusion extends on average
$11.3 \mathrm{~km}$ and up to $16.8 \mathrm{~km}$ inland during higher spring tides (September). The influence of spring tides extends approximately $40 \mathrm{~km}$ upstream, comprising a total estuarine area of $23 \mathrm{~km}^{2}$ (Sousa et al., 2005). The Minho is considered to be a relatively low impacted estuary and has been used as a reference location in several ecological and ecotoxicological studies (Guimarães et al., 2009, 2012). Due to its high ecological value, presenting a large diversity of habitats and biodiversity and relatively low human intervention, the Minho is one of the three Portuguese estuaries included in the LTER (Long-Term Ecosystem Research) Portugal and LTER Europe programmes. It is also included in the Natura 2000 Network (Pinto and Martins, 2013).

The Lima River rises in Spain in Sierra de San Mamed and its mouth is located in Viana do Castelo (Portugal), after a course of $108 \mathrm{~km}$ (67 km in Portuguese territory) draining into the Atlantic Ocean. Its basin has an area of $2480 \mathrm{~km}^{2}\left(1177 \mathrm{~km}^{2}\right.$ in Portugal: $47 \%$ and $1303 \mathrm{~km}^{2}$ in Spain: 53\%). The Lima estuary (hereafter designated as Lima) has a semidiurnal and mesotidal regime (the tidal range is about $3.7 \mathrm{~m}$ ), partially mixed, with an average flushing rate of $0.4 \mathrm{~m} / \mathrm{s}$ and an annual average river flow of $70 \mathrm{~m}^{3} / \mathrm{s}$. The influence of spring tides extends approximately $20 \mathrm{~km}$ upstream and comprises a total estuarine area of approximately $6 \mathrm{~km}^{2}$. It has a maximum width of approximately $1 \mathrm{~km}$, being significantly larger with the flooding of the banks during high tide (Sousa et al., 2006; Ramos et al., 2009). The mean residence time in the estuarine area is one day, which is in part responsible for a high capacity to dilute and flush nutrients. Lima has been subjected to several anthropogenic impacts in recent years, being the recipient for diffuse pollution originating from domestic and industrial waste discharges and agricultural runoff, transporting nutrients and other substances into the estuarine area. In addition, an important harbour, located at the mouth of the river, leads to continuous petrochemical contamination through the activity of commercial and fishing containers. Also, in the most downstream part of the Lima estuary, a $3 \mathrm{~km}$ navigational channel is maintained by regular dredging activities (Costa-Dias et al., 2010; Azevedo et al., 2013).

\subsection{Field collections}

Sampling was carried out once at each season, in July 2012, November 2012, February 2013, and June 2013, at each of the four transects in the Minho and Lima estuaries. To examine and compare the feeding ecology of $P$. microps larvae we measured $\delta^{15} \mathrm{~N}$ and $\delta^{13} \mathrm{C}$ in zooplankton food sources and fish larvae consumers. To assess the water quality of the Minho and Lima waters, we measured concentrations of ammonium $\left(\mathrm{NH}_{4}{ }^{+}\right)$, nitrate $\left(\mathrm{NO}_{3}{ }^{-}\right)$, phosphate $\left(\mathrm{PO}_{4}{ }^{3-}\right)$, and chlorophyll $a$ in the water column. We also compared the $\delta^{15} \mathrm{~N}$ in food sources and consumers between the two sites as a measure of the nutrient enrichment.

Fish larvae assemblages were sampled along each estuary, using a hand operated net (mesh size: $1 \mathrm{~mm}$ ) at low tide, at stations $\mathrm{S} 1$ in Minho, and S2 in Lima, (Minho: $41^{\circ} 52^{\prime} 51.73^{\prime \prime} \mathrm{N}, 8^{\circ} 50^{\prime} 8.12 \mathrm{~W}$; Lima: $41^{\circ} 41^{\prime} 11.32^{\prime \prime} \mathrm{N}, 8^{\circ} 49^{\prime} 19.34 \mathrm{~W}$ ) (Fig. 1), both located between transects $\mathrm{T} 2$ and $\mathrm{T} 3$, and identified as areas supporting high abundance of the goby larvae. Four replicates were taken at S1 and S2, for all sampling dates. In both estuaries, the spatial water column and zooplankton sampling was performed, from the south to the north riverbank, along four equidistant transects, as in Vieira et al. (2015) (Fig. 1). One sample was collected per transect, on each sampling date. In these two highly dynamic systems the circulation of waters/zooplankton communities across transects is quite high, and, accordingly, samples from the four transects were used as replicates. A global position system (GPS) (HP IPAQ GPSMAP) was used to determine, and validate the coordinates of the sampling sites for each date.

Temporal variations in the physicochemical environment and pelagic zooplankton communities were investigated, during high spring tides, in the four selected transects. Salinity and temperature $\left({ }^{\circ} \mathrm{C}\right)$ were measured in situ, with a multi-parameter probe (VWR SP90M5), and the 
salinity was measured using the Practical Salinity Scale. Additionally, at each transect, water samples were also collected with polyethyleneterephthalate bottles and stored at $-20{ }^{\circ} \mathrm{C}$ for nutrient analysis; levels of ammonium, nitrate, and phosphate were measured using commercial photometer kits (Palintest Photometer 7000, Kingsway, England). For all determinations, three replicates were collected from the middle of the water column, as in Vieira et al. (2015) (Fig. 1). Pelagic zooplankton was collected at each site by horizontal tows, using plankton nets with a mesh size of $335 \mu \mathrm{m}$, at approximately the same depth of the water sampling, at an average tow speed of 2 knots.

Water for nutrient concentration $(700 \mathrm{ml})$ was filtered through a pre-combusted $0.45 \mu \mathrm{m}$ pore size, $4.7 \mathrm{~cm}$ diameter glass fibre filters (Whatman GF/F filter). Water samples were stored on ice until arrival at the laboratory, when they were transferred to the freezer $\left(-18{ }^{\circ} \mathrm{C}\right)$. Chlorophyll $a$ level was also determined in water samples, following the methodology described by Aminot and Rey (2001), as in Vieira et al. (2015). POM (particulate organic matter) was obtained by first removing larger zooplankton and macrodetritus from the sample by prefiltering the water through $63 \mu \mathrm{m}$ mesh, and then filtering $\sim 51$ of the remaining seawater, from a depth of $0.5 \mathrm{~m}$ below the surface, onto precombusted $\left(450^{\circ} \mathrm{C}, 4 \mathrm{~h}\right)$ Whatman GF/F filters with a low-pressure vacuum pump. The zooplankton samples for isotope analysis were composites of 20-200 individuals, and for larvae $P$. microps a minimum of 5-10 individuals were used; all individuals were sorted alive. All samples were carefully cleaned, rinsed with Milli-Q water and freezedried. When dry, samples were ground (filters with POM were kept whole) into homogenous powder using a mixer mill, weighted, and loaded into tin capsules. For fish, the muscle from the dorsal region was analysed.

\subsection{Analytical technique and data analyses}

The carbon and nitrogen isotopic composition of the samples was determined using a Flash EA 1112 Series elemental analyser coupled on line via Finningan ConFlo III interface to a Thermo delta V S mass spectrometer. The carbon and nitrogen isotope ratios are expressed in delta $(\delta)$ notation, defined as the parts per thousand (\%o), a deviation from a standard material (PDB limestone for $\delta^{13} \mathrm{C}$ and atmospheric nitrogen for $\left.\delta^{15} \mathrm{~N}\right)$ : $\delta^{13} \mathrm{C}$ or $\delta^{15} \mathrm{~N}=$ [(Rsample/Rstandard) 1] $\times 1000$, where $\mathrm{R}={ }^{13} \mathrm{C} /{ }^{12} \mathrm{C}$ or ${ }^{15} \mathrm{~N} /{ }^{14} \mathrm{~N}$. The precision in the overall preparation and analysis was better than $0.1 \%$ for $\delta^{13} \mathrm{C}$ and $0.3 \%$ for $\delta^{15} \mathrm{~N}$.

To test for differences in the $\delta^{15} \mathrm{~N}$ and $\delta^{13} \mathrm{C}$ values of consumers between size classes (two levels: class $0,0-10 \mathrm{~mm}$; class $1,10-15 \mathrm{~mm}$; fixed), estuaries (two levels: Minho and Lima; fixed), and time (three: July 2012, November 2012 and June 2013; fixed), we used a three-way model analysis of variance (ANOVA). February 2013 was not considered in the analysis because fish larvae of size class 0 were not present in the samples. Thus, to test for differences in the $\delta^{15} \mathrm{~N}$ and $\delta^{13} \mathrm{C}$ values of consumers of size class 1 between estuaries and the four sampling dates (July 2012, November 2012, February 2013 and June 2013) we used a two-way ANOVA. Homogeneity of variances (Bartlett chi-square test) and normality of models residuals (Normal p-p) were checked in all instances. Tukey's honest significant difference (HSD) test was used as a multiple comparison test to identify differences between treatments for significant factors or interactions in the ANOVAs. All statistical analyses were performed on STATISTICA 7 software (StatSoft Inc., Tulsa, Oklahoma, U.S.A.).

To determine if the isotopic signatures of food sources varied between estuaries and time, to account for data heteroscedasticity, we used a two-way Permutational Multivariate Analysis of Variance (PERMANOVA) (Anderson, 2001). The dependent variables $\delta^{13} \mathrm{C}$ and $\delta^{15} \mathrm{~N}$ signatures were compared independently between the fixed factors: estuaries (Minho and Lima) and time (July 2012, November 2012, February 2013, and June 2013). When appropriate, a posteriori multiple comparisons were used to test for differences between/within groups for pairs of levels of factors, and Monte Carlo tests were included where insufficient unique permutations existed for meaningful tests $(<150)$. The tests were based on Euclidean distance matrices using 9999 unrestricted permutations of raw data and calculated from normalised, untransformed data. Statistical analyses were conducted using Primer v.6 and PERMANOVA (Primer-E Ltd., Plymouth, UK).

To evaluate the influence of each environmental variable on the stable nitrogen and carbon isotopic signatures of all zooplankton groups/species, a Pearson correlation analysis was performed (SPSS 21.0). This analysis was also used to explore the strength of association between the $\delta^{15} \mathrm{~N}$ and $\delta^{13} \mathrm{C}$ of the consumer $P$. microps larvae and possible food sources.

To estimate contributions for each dietary source to the diet of $P$. microps larvae, we adopted a Bayesian stable-isotope mixing model (stable isotope analyses in R: SIAR; Parnell et al., 2010), which allows the inclusion of isotopic signatures, elemental concentrations and fractionation together with the uncertainly of these values within the model. Before running this model, fractionation values of $+3.54 \% 0 \pm 0.74$ for $\delta^{15} \mathrm{~N}$ and $1.63 \% 0 \pm 0.63$ for $\delta^{13} \mathrm{C}$ were used following Cummings et al. (2012). The model was run separately for each sampling date, for both estuaries.

\section{Results}

\subsection{Environmental variables}

Ammonium, nitrate, phosphate, salinity, and temperature exhibited similar patterns of variation at Minho and Lima over the study period (Table 1), with considerable temporal differences. Ammonium and nitrate were higher in Lima, across the sampling dates, with the highest values registered in February 2013 (2.67 and $1.00 \mathrm{mg} \mathrm{L}^{-1}$, respectively), and in November 2012 (1.15 and $0.50 \mathrm{mg} \mathrm{L}^{-1}$, respectively) while, in Minho, ammonium and nitrate showed values of 2.12 and $0.50 \mathrm{mg} \mathrm{L}^{-1}$, respectively, in February 2013, and of 0.73 and

Table 1

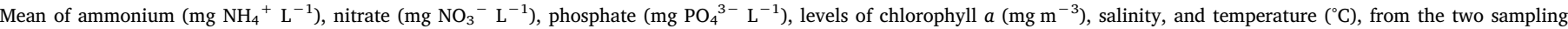
estuaries, Minho and Lima, Portugal, across the sampling dates.

\begin{tabular}{|c|c|c|c|c|c|c|c|}
\hline & Ammonium & Nitrate & Phosphate & Chlorophyll $a$ & Salinity & Temperature & $N$ \\
\hline \multicolumn{8}{|l|}{ Minho } \\
\hline Jul 2012 & $0.44 \pm 0.72$ & $0.03 \pm 1.48$ & $0.05 \pm 0.07$ & $2.60 \pm 1.30$ & $31.90 \pm 3.80$ & $17.10 \pm 1.48$ & 12 \\
\hline Nov 2012 & $0.73 \pm 0.15$ & $0.40 \pm 0.38$ & $0.25 \pm 0.40$ & $0.29 \pm 0.09$ & $0.25 \pm 0.92$ & $12.00 \pm 0.28$ & 12 \\
\hline Feb 2013 & $2.12 \pm 0.80$ & $0.50 \pm 0.36$ & $0.07 \pm 0.04$ & $0.75 \pm 0.13$ & $0.25 \pm 0.73$ & $11.55 \pm 0.28$ & 12 \\
\hline Jun 2013 & $0.08 \pm 0.37$ & $0.27 \pm 0.17$ & $0.10 \pm 0.15$ & $1.25 \pm 0.91$ & $20.45 \pm 5.24$ & $22.06 \pm 0.60$ & 12 \\
\hline \multicolumn{8}{|l|}{ Lima } \\
\hline Jul 2012 & $0.71 \pm 0.90$ & $0.02 \pm 0.27$ & $0.10 \pm 0.07$ & $5.50 \pm 3.34$ & $32.40 \pm 1.26$ & $15.90 \pm 0.65$ & 12 \\
\hline Nov 2012 & $1.15 \pm 0.43$ & $0.50 \pm 0.31$ & $0.07 \pm 0.07$ & $0.32 \pm 0.23$ & $13.65 \pm 4.57$ & $14.10 \pm 0.54$ & 12 \\
\hline Feb 2013 & $2.67 \pm 1.25$ & $1.00 \pm 0.44$ & $0.02 \pm 0.14$ & $1.13 \pm 0.08$ & $10.20 \pm 4.41$ & $11.34 \pm 0.19$ & 12 \\
\hline Jun 2013 & $0.40 \pm 0.34$ & $0.26 \pm 0.18$ & $0.30 \pm 0.18$ & $2.34 \pm 1.23$ & $28.05 \pm 5.13$ & $20.95 \pm 1.17$ & 12 \\
\hline
\end{tabular}


Table 2

$\delta^{15} \mathrm{~N}$ and $\delta^{13} \mathrm{C}$ of zooplankton groups/species collected from the Minho and Lima estuaries, Portugal. Data are sample size ( $N$ ), and mean $\delta$ values ( \pm SD), for all sampling dates.

\begin{tabular}{|c|c|c|c|c|c|c|c|}
\hline \multirow[b]{2}{*}{ Group/species } & \multirow[b]{2}{*}{ Abbreviation } & \multicolumn{3}{|l|}{ Minho } & \multicolumn{3}{|l|}{ Lima } \\
\hline & & $\delta^{15} \mathrm{~N}$ & $\delta^{13} \mathrm{C}$ & $N$ & $\delta^{15} \mathrm{~N}$ & $\delta^{13} \mathrm{C}$ & $N$ \\
\hline Particulate organic matter & POM & $5.2 \pm 0.4$ & $-21.5 \pm 0.8$ & 16 & $5.7 \pm 0.9$ & $-21.8 \pm 0.5$ & 16 \\
\hline Cirripedia & Cir & $6.3 \pm 0.2$ & $-21.1 \pm 1.2$ & 10 & $6.5 \pm 0.7$ & $-20.6 \pm 0.5$ & 10 \\
\hline Cladocera & Cla & $5.9 \pm 0.8$ & $-21.6 \pm 0.9$ & 14 & $6.8 \pm 0.8$ & $-20.8 \pm 0.8$ & 12 \\
\hline Copepoda & Cop & $7.5 \pm 0.5$ & $-20.0 \pm 0.4$ & 16 & $8.6 \pm 1.1$ & $-19.6 \pm 0.5$ & 16 \\
\hline Mysidacea & Mys & $7.6 \pm 0.9$ & $-21.1 \pm 0.9$ & 16 & $9.0 \pm 1.2$ & $-21.0 \pm 1.2$ & 16 \\
\hline Sagitta friderici & Sag & $9.3 \pm 0.7$ & $-21.1 \pm 0.3$ & 4 & $10.0 \pm 0.6$ & $-20.6 \pm 0.9$ & 4 \\
\hline Zoea (decapod) & Zoea & $6.0 \pm 0.5$ & $-19.2 \pm 1.3$ & 8 & $7.0 \pm 1.1$ & $-19.5 \pm 1.0$ & 8 \\
\hline Pomatoschistus microps larvae (size 0-10 mm) & & $10.5 \pm 0.3$ & $-17.9 \pm 0.4$ & 12 & $11.8 \pm 0.8$ & $-18.1 \pm 0.3$ & 12 \\
\hline Pomatoschistus microps larvae (size $10-15 \mathrm{~mm}$ ) & & $10.8 \pm 0.5$ & $-17.5 \pm 0.4$ & 16 & $12.2 \pm 0.4$ & $-17.8 \pm 0.3$ & 16 \\
\hline
\end{tabular}

$0.40 \mathrm{mg} \mathrm{L}^{-1}$, respectively, in November 2012. Phosphate concentrations were lower, at both estuaries and on all sampling dates, compared to ammonium and nitrate. Chlorophyll $a$ concentration was higher in July 2012 and June 2013, with mean higher values in Lima (5.50 and $2.35 \mathrm{mg} \mathrm{m}^{-3}$, respectively). Salinity variations had a stronger expression in Minho, with values near zero observed in November 2012 and February 2013. Water temperature showed a seasonal cycle in both estuaries, with higher values in the July 2012 and June 2013 (warmer months), and lower values in February 2013 (the coldest sampling date) (Table 1).

\subsection{Stable isotope analysis}

$\delta^{15} \mathrm{~N}$ and $\delta^{13} \mathrm{C}$ values obtained for the consumer $P$. microps larvae and potential zooplankton food sources, collected in July 2012, November 2012, February 2013 and June 2013, from the Minho and Lima estuaries, are summarised in Table 2. Overall, visually comparing the stable isotope dual-plots for each estuary and sampling date (Fig. 2), it is clear that the food web structure was similar among sampling dates and estuaries, with the same potential food resources being identified in both estuaries, and that there are some marked differences in the $\delta^{15} \mathrm{~N}$ and $\delta^{13} \mathrm{C}$ in consumers and food sources.

The mean $\delta^{15} \mathrm{~N}$ values obtained for the consumer $P$. microps larvae size classes (class 0: 0-10 mm; class 1: 10-15 mm) did not differ significantly, but varied significantly between estuaries, sampling dates and estuary $\mathrm{x}$ time interaction $(p<0.001$; Table 3$)$. P. microps larvae size classes from Lima showed significantly higher nitrogen isotope ratios than their counterparts in Minho, on average 1.4\%o heavier, for all sampling dates (Table 4). In Lima, the $\delta^{15} \mathrm{~N}$ values showed significant differences among the sampling dates, with higher values in November 2012, for both size classes (Tukey test, $p<0.005$; Table 4). For $\delta^{13} \mathrm{C}$, the analyses revealed significantly differences between size classes, estuaries, estuary $\mathrm{x}$ time interaction, and size $\mathrm{x}$ estuary $\mathrm{x}$ time interaction $(p<0.001$; Table 3$)$. The carbon isotope signature for goby larvae size class 0 was, on average, $0.6 \%$ depleted comparing to size class 1; depleted values were observed in Lima, for both size classes, in November 2012 (Tukey test, $p<0.012$; Table 4), while, in Minho, depleted carbon ratios were exhibited in July 2012 and June 2013 (Tukey test, $p<0.018$; Table 4).

Two-way ANOVA, obtained for the consumer P. microps larvae size classe 1 , showed significant differences between estuaries, time, and estuary $\mathrm{x}$ time interaction, for both $\delta^{15} \mathrm{~N}$ and $\delta^{13} \mathrm{C}(p<0.001$; Table 3). With regard to $\delta^{15} \mathrm{~N}$, enriched signatures were observed in the coldest months in Lima (November 2012 and February 2013 from Lima differed from all the other sampling dates, considering both estuaries; Tukey test, $p<0.001$; Table 5); in Minho, $\delta^{15} \mathrm{~N}$ enrichment was found in February 2013 (Tukey test, $p<0.001$; Table 5). For $\delta^{13} \mathrm{C}, P$. microps larvae in Lima exhibited depleted values in February 2013, compared to all sampling dates in Minho (Tukey test, $p<0.016$; Table 5).

Regarding sources, similar patterns were observed for the group/ species collected on all sampling dates (Cirripedia, Cladocera,
Copepoda, Mysidacea, POM). The mean $\delta^{15} \mathrm{~N}$ values obtained for the food resources varied significantly between estuaries, time, and estuary $\mathrm{x}$ time interaction $(p<0.001$; Table 6$)$. Examination of PERMANOVA interaction term showed that the mean $\delta^{15} \mathrm{~N}$ values were significantly enriched in Lima (vs. Minho) in November 2012 and February 2013 (Table 6: PERMANOVA interaction $p$ (perm) <0.05), with significant temporal differences across groups. Lima $\delta^{15} \mathrm{~N}$ values were also higher in colder months (PERMANOVA pairwise: $p$ (perm) < 0.05), while, significantly, in Minho $\delta^{15} \mathrm{~N}$ enrichment was observed in February 2013 (PERMANOVA pairwise: $p$ (perm) <0.05). For $\delta^{13} \mathrm{C}$, significantly enriched values were observed in Lima, in warmer months (PERMANOVA pairwise: $p$ (perm) < 0.05), compared to Minho. Comparing sampling dates, both estuaries showed temporal significant differences, with enriched carbon isotope ratios occurring in July 2012 (PERMANOVA pairwise: $p$ (perm) < 0.05). With regard to Sagitta friderici and Zoea, no differences were found for $\delta^{15} \mathrm{~N}$ and $\delta^{13} \mathrm{C}$ signatures across treatments (Table 6).

\subsection{Correlation analysis of zooplankton stable isotopes and environmental} factors

$\delta^{15} \mathrm{~N}$ values of the consumer $P$. microps larvae were positively correlated with most potential zooplankton food sources in both estuaries. $\delta^{15} \mathrm{~N}$ ratios of the consumer and several food sources were positively correlated with ammonium in Minho and Lima, and negatively correlated with average salinity (Table 7 ). $\delta^{13} \mathrm{C}$ values were positively correlated with salinity in Lima and Minho, and negatively correlated with ammonium in Lima. Overall, correlation values between ammonium and $\delta^{15} \mathrm{~N}$ matrices were high, showing that the strongest single predictor of variability in $\delta^{15} \mathrm{~N}$ signatures of zooplankton was ammonium (Table 7).

\subsection{Mixing model outputs}

Statistical comparisons between potential food resource contribution to the consumer diet estimated by SIAR were performed for each estuary and sampling date (Table 8). The Bayesian mixing model outcomes revealed a mixed use of all food sources by the consumer $P$. microps larvae, in both estuaries and on all sampling dates, with temporal differences in the relative proportion of sources ingested. Copepods, a group composed primarily of Acartia sp., were the most consumed item in both estuaries on all sampling dates, displaying proportion values from $34 \%$ to $60 \%$, with higher contributions in November 2012 and February 2013, in both estuaries (Table 8).

In Minho, in warmer months, $P$. microps larvae exploited mostly copepods ( $41 \%$ and $35 \%$, respectively), Mysidacea (19\% and $16 \%$, respectively), and brachyuran zoea (Crustacea: Decapoda) (17\% and $29 \%$, respectively). In November 2012, copepods accounted for $34 \%$ of the consumer diet, whereas POM, Mysidacea, and $S$. friderici showed contributions of $27 \%, 21 \%$ and $18 \%$, respectively. In February 2013 , the consumer relied mainly on copepods (41\%), Mysidacea (28\%), and 


\section{MINHO}
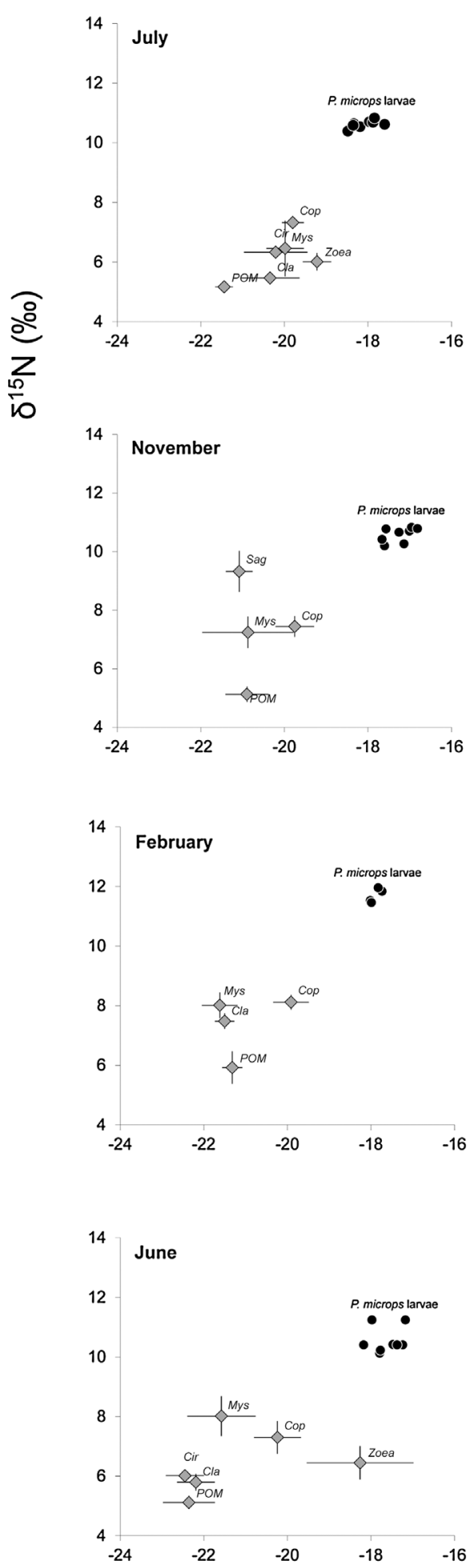

LIMA

14

12

July
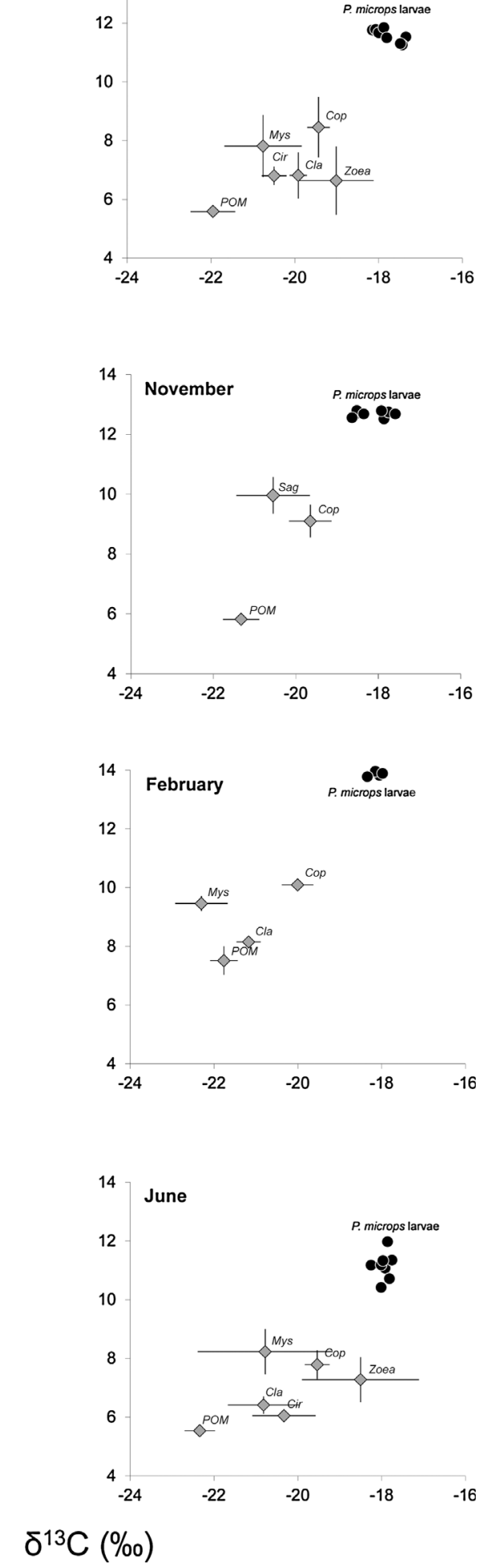

Fig. 2. $\delta^{13} \mathrm{C}$ versus $\delta^{15} \mathrm{~N}$ of zooplankton groups/species, in Minho (left) and Lima (right), Portugal, across the sampling dates. The abbreviations of the groups/species are shown on Table 2.
Cladocera (21\%) (Table 8).

In Lima, the relative importance of all food sources to the diet of $P$. microps larvae was similar to the one found in Minho. In July 2012 and June 2013, the three main food sources were copepods (46\% and $37 \%$, respectively), Mysidacea ( $17 \%$ and $18 \%$, respectively), and brachyuran zoea (14\% and 23\%, respectively). In November 2012, copepods,
Sagitta friderici and POM had a percentage contribution of $48 \%, 40 \%$, and $12 \%$, respectively, while February 2013, P. microps larvae showed a high consumption of copepods (60\%), followed by Mysidacea (17\%), and Cladocera (13\%) (Table 8). 
Table 3

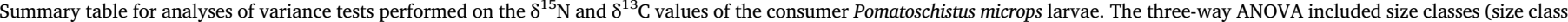

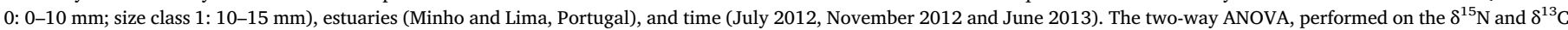
values of the size classe $1(10-15 \mathrm{~mm}$ ) included estuaries (Minho and Lima) and time (July 2012, November 2012, February 2013 and June 2013). Data were untransformed.

\begin{tabular}{|c|c|c|c|c|c|c|c|}
\hline & \multirow[b]{2}{*}{$\mathrm{df}$} & \multicolumn{3}{|l|}{$\delta^{15} \mathrm{~N}$} & \multicolumn{3}{|l|}{$\delta^{13} \mathrm{C}$} \\
\hline & & MS & $\mathrm{F}$ & $P$ & MS & $\mathrm{F}$ & $P$ \\
\hline \multicolumn{8}{|l|}{ three-way ANOVA } \\
\hline Intercept & 1 & 6017.02 & 69522.19 & $<0.001$ & 15172.07 & 512794.62 & $<0.001$ \\
\hline Size & 1 & 0.06 & 0.68 & 0.416 & 3.63 & 122.56 & $<0.001$ \\
\hline Estuary & 1 & 17.82 & 205.90 & $<0.001$ & 1.50 & 50.69 & $<0.001$ \\
\hline Time & 2 & 2.49 & 28.73 & $<0.001$ & 0.09 & 3.08 & 0.058 \\
\hline Size*Estuary & 1 & 0.05 & 0.58 & 0.452 & 0.06 & 1.93 & 0.173 \\
\hline Size*Time & 2 & 0.12 & 1.39 & 0.261 & 0.07 & 2.33 & 0.112 \\
\hline Estuary*Time & 2 & 2.47 & 28.57 & $<0.001$ & 1.12 & 37.81 & $<0.001$ \\
\hline Size*Estuary*Time & 2 & 0.16 & 1.87 & 0.168 & 0.16 & 5.39 & 0.009 \\
\hline Error & 36 & 0.09 & & & 0.03 & & \\
\hline \multicolumn{8}{|l|}{ two-way ANOVA } \\
\hline Intercept & 1 & 4319.50 & 56676.04 & $<0.001$ & 9918.94 & 381074.13 & $<0.001$ \\
\hline Estuary & 1 & 15.85 & 207.97 & $<0.001$ & 1.45 & 55.74 & $<0.001$ \\
\hline Time & 3 & 5.53 & 72.57 & $<0.001$ & 0.37 & 14.33 & $<0.001$ \\
\hline Estuary*Time & 3 & 1.32 & 17.27 & $<0.001$ & 0.19 & 7.40 & 0.001 \\
\hline Error & 24 & 0.08 & & & 0.03 & & \\
\hline
\end{tabular}

Table 4

$\delta^{15} \mathrm{~N}$ and $\delta^{13} \mathrm{C}$ of the consumer Pomatoschistus microps larvae (size class 0: 0-10 mm; size class 1: 10-15 mm) collected from the Minho and Lima estuaries, Portugal, in July 2012, November 2012, and June 2013. Values are means \pm SD. Treatments with the same letter do not significantly differ (one-way ANOVA followed by Tukey's HSD test, $P>0.050)$.

\begin{tabular}{|c|c|c|c|c|c|}
\hline Size class & Estuary & Time & $n$ & $\delta^{15} \mathrm{~N}$ & $\delta^{13} \mathrm{C}$ \\
\hline 0 & Minho & Jul 2012 & 4 & $10.54 \pm 0.11^{\mathrm{a}}$ & $-18.34 \pm 0.12^{\mathrm{ba}}$ \\
\hline 0 & Minho & Nov 2012 & 4 & $10.52 \pm 0.27^{\mathrm{a}}$ & $-17.46 \pm 0.30^{\mathrm{efg}}$ \\
\hline 0 & Minho & Jun 2013 & 4 & $10.50 \pm 0.51^{\mathrm{a}}$ & $-17.93 \pm 0.19^{\mathrm{cdt}}$ \\
\hline 0 & Lima & Jul 2012 & 4 & $11.77 \pm 0.07^{\mathrm{d}}$ & $-18.02 \pm 0.12^{\mathrm{cb}}$ \\
\hline 0 & Lima & Nov 2012 & 4 & $12.68 \pm 0.10^{\mathrm{e}}$ & $-18.52 \pm 0.12^{\mathrm{a}}$ \\
\hline 0 & Lima & Jun 2013 & 4 & $10.97 \pm 0.37^{\mathrm{abc}}$ & $-18.05 \pm 0.14^{\mathrm{cb}}$ \\
\hline 1 & Minho & Jul 2012 & 4 & $10.71 \pm 0.09^{\mathrm{abc}}$ & $-17.52 \pm 0.20^{\mathrm{def}}$ \\
\hline 1 & Minho & Nov 2012 & 4 & $10.63 \pm 0.26^{\mathrm{ab}}$ & $-17.04 \pm 0.20^{\mathrm{g}}$ \\
\hline 1 & Minho & Jun 2013 & 4 & $10.62 \pm 0.42^{\mathrm{a}}$ & $-17.32 \pm 0.13^{\mathrm{fg}}$ \\
\hline 1 & Lima & Jul 2012 & 4 & $11.40 \pm 0.14^{\mathrm{cd}}$ & $-17.52 \pm 0.20^{\mathrm{def}}$ \\
\hline 1 & Lima & Nov 2012 & 4 & $12.68 \pm 0.12^{\mathrm{e}}$ & $-17.78 \pm 0.15^{\mathrm{cde}}$ \\
\hline 1 & Lima & Jun 2013 & 4 & $11.35 \pm 0.51^{\mathrm{bcd}}$ & $-17.85 \pm 0.09^{\mathrm{cd}}$ \\
\hline
\end{tabular}

Table 5

$\delta^{15} \mathrm{~N}$ and $\delta^{13} \mathrm{C}$ of the consumer Pomatoschistus microps larvae (size class 1: 10-15 mm) collected from the Minho and Lima estuaries, Portugal, in July 2012, November 2012, February 2013, and June 2013. Values are means \pm SD. Treatments with the same letter do not significantly differ (one-way ANOVA followed by Tukey's HSD test, $P>0.050$ ).

\begin{tabular}{lllll}
\hline Estuary & Time & $n$ & $\delta^{15} \mathrm{~N}$ & \multicolumn{2}{l}{$\delta^{13} \mathrm{C}$} \\
\hline Minho & Jul 2012 & 4 & $10.71 \pm 0.09^{\mathrm{ab}}$ & $-17.52 \pm 0.20^{\mathrm{bc}}$ \\
Minho & Nov 2012 & 4 & $10.63 \pm 0.26^{\mathrm{a}}$ & $-17.04 \pm 0.20^{\mathrm{d}}$ \\
Minho & Feb 2013 & 4 & $11.70 \pm 0.24^{\mathrm{c}}$ & $-17.70 \pm 0.13^{\mathrm{bc}}$ \\
Minho & Jun 2013 & 4 & $10.62 \pm 0.42^{\mathrm{a}}$ & $-17.32 \pm 0.13^{\mathrm{cd}}$ \\
Lima & Jul 2012 & 4 & $11.40 \pm 0.14^{\mathrm{c}}$ & $-17.52 \pm 0.20^{\mathrm{bc}}$ \\
Lima & Nov 2012 & 4 & $12.68 \pm 0.12^{\mathrm{d}}$ & $-17.78 \pm 0.15^{\mathrm{ab}}$ \\
Lima & Feb 2013 & 4 & $13.86 \pm 0.08^{\mathrm{e}}$ & $-18.13 \pm 0.16^{\mathrm{a}}$ \\
Lima & Jun 2013 & 4 & $11.35 \pm 0.51^{\mathrm{bc}}$ & $-17.85 \pm 0.09^{\mathrm{ab}}$ \\
\hline
\end{tabular}

\section{Discussion}

\subsection{Diet of Pomatoschistus microps larvae}

The present study provides new information on the feeding ecology of $P$. microps larvae in estuarine ecosystems. Bayesian mixing models revealed that this estuarine resident species is planktivorous during its larval stage of development, feeding on both planktonic-hyperbenthic prey, in both estuaries, mainly on copepods, mysids, and brachyuran zoea. These groups of prey items and also euphausiids tend to be more abundant in the diets of marine rather than freshwater species, largely because they are usually more abundant or only present in marine environments, whereas rotifers, cyclopoid copepods, cladocerans, and insects are most important in the diets of freshwater species (Nunn et al., 2012). The larvae and juveniles of fishes inhabiting tidal rivers or upper estuaries, such as the common goby, frequently have diets containing both marine and freshwater taxa (Nunn et al., 2012), and our results support these observations. Our findings agree with Thiel et al. (1996) who reported that Calanoida (eggs, nauplii, copepodites, adults), Harpacticoida, Chydoridae (Crustacea: Cladocera), and Mysidacea were the food choice of common goby larvae in three German estuaries.

The similarity found between the Minho and Lima estuaries, in terms of relative importance of food sources to the diet of $P$. microps, is not surprising considering several comparable conditions of the two estuaries and their proximity. Copepods were the preferred prey of goby larvae in both estuaries, on all sampling dates. In fact, Vieira et al. (2015) reported that copepods were the most representative taxa in both estuaries, with $86.8 \%$ and $76.3 \%$ at Minho and Lima, respectively, followed by Cirripedia, with contributions of $5.6 \%$ at Minho and $4.4 \%$ at Lima. However, for mysids and brachyuran zoea, the largest food items consumed, the contributions were lower than $1.5 \%$. These observations suggest that prey size was also an important driver of prey preference, since mysids and brachyuran zoea displayed proportion values from $16 \%$ to $29 \%$ of the common goby larvae diet. Therefore, it is interesting to note that this study reveals some degree of specialisation in the feeding strategy of $P$. microps larvae, focusing on prey from a specific weight (size) range, whatever the considered sampling date. Similar observations were only reported by Pasquaud et al. (2010) for adult fishes of the studied taxon. According to Lazzaro (1987), a few weeks after the eggs hatch, fish larvae are able to consume prey of the maximum available size. Prey selection is driven by the ratio of energy gained over energy expended for its capture, so prey selectivity is likely to be correlated with prey abundance and prey size (Robert et al., 2014). This is in accordance with the Optimal Foraging Theory (MacArthur and Pianka, 1966) as the energetic content of a given prey type increases with its size, but there is also an associated increase in handling time; so, for a fish larvae predator, prey selection must provide the maximum of energy gain per unit of handling time.

The relative importance of cladocerans to the diet of $P$. microps larvae can be attributable to their ease of capture compared to copepods, with the latter being faster moving, numerically abundant and of 
Table 6

Results of two-way PERMANOVA testing for differences in $\delta^{15} \mathrm{~N}$ and $\delta^{13} \mathrm{C}$ values of the food sources (Cirripedia, Cladocera, Copepoda, Mysidacea, Sagitta friderici, brachyuran zoea, POM) between estuaries (Minho and Lima, Portugal) and time (July 2012, November 2012, February 2013, and June 2013).

\begin{tabular}{|c|c|c|c|c|c|c|c|}
\hline & \multicolumn{7}{|c|}{ Cirripedia } \\
\hline & \multirow[b]{2}{*}{$\mathrm{df}$} & \multicolumn{3}{|l|}{$\delta^{15} \mathrm{~N}$} & \multicolumn{3}{|l|}{$\delta^{13} \mathrm{C}$} \\
\hline & & MS & $F$ & $P$ & MS & $F$ & $P$ \\
\hline E-Estuary & 1 & 1.54 & 48.39 & $<0.001$ & 1.05 & 3.39 & 0.088 \\
\hline T-Time & 2 & 1.62 & 51.13 & $<0.001$ & 2.64 & 8.52 & 0.002 \\
\hline $\mathrm{Ex} \mathrm{T}$ & 2 & 0.70 & 22.12 & $<0.001$ & 2.76 & 8.91 & 0.003 \\
\hline Res & 14 & 0.03 & & & 0.31 & & \\
\hline Total & 19 & & & & & & \\
\hline
\end{tabular}

\begin{tabular}{|c|c|c|c|c|c|c|c|}
\hline & \multicolumn{7}{|c|}{ Cladocera } \\
\hline & \multirow[b]{2}{*}{$\mathrm{df}$} & \multicolumn{3}{|l|}{$\delta^{15} \mathrm{~N}$} & \multicolumn{3}{|l|}{$\delta^{13} \mathrm{C}$} \\
\hline & & MS & $F$ & $P$ & MS & $F$ & $P$ \\
\hline E-Estuary & 1 & 3.76 & 24.86 & $<0.001$ & 2.00 & 7.66 & 0.014 \\
\hline T-Time & 3 & 3.94 & 26.06 & $<0.001$ & 3.66 & 14.07 & $<0.001$ \\
\hline $\mathrm{E} \times \mathrm{T}$ & 3 & 0.16 & 1.06 & 0.394 & 0.28 & 1.08 & 0.382 \\
\hline Res & 18 & 0.15 & & & 0.26 & & \\
\hline Total & 25 & & & & & & \\
\hline
\end{tabular}

\begin{tabular}{|c|c|c|c|c|c|c|c|}
\hline & \multicolumn{7}{|c|}{ Copepoda } \\
\hline & \multirow[b]{2}{*}{$\mathrm{df}$} & \multicolumn{3}{|l|}{$\delta^{15} \mathrm{~N}$} & \multicolumn{3}{|l|}{$\delta^{13} \mathrm{C}$} \\
\hline & & MS & $F$ & $P$ & MS & $F$ & $P$ \\
\hline E-Estuary & 1 & 10.32 & 38.94 & $<0.001$ & 0.60 & 3.58 & 0.075 \\
\hline T-Time & 3 & 4.10 & 15.46 & $<0.001$ & 0.59 & 5.53 & 0.032 \\
\hline $\mathrm{E} \times \mathrm{T}$ & 3 & 1.38 & 5.20 & 0.007 & 0.21 & 1.25 & 0.315 \\
\hline Res & 24 & 0.27 & & & 0.17 & & \\
\hline Total & 31 & & & & & & \\
\hline
\end{tabular}

\begin{tabular}{|c|c|c|c|c|c|c|c|}
\hline & \multicolumn{7}{|c|}{ Mysidacea } \\
\hline & \multirow[b]{2}{*}{ df } & \multicolumn{3}{|l|}{$\delta^{15} \mathrm{~N}$} & \multicolumn{3}{|l|}{$\delta^{13} \mathrm{C}$} \\
\hline & & MS & $F$ & $P$ & MS & $F$ & $P$ \\
\hline E-Estuary & 1 & 11.76 & 16.29 & $<0.001$ & 0.36 & 0.45 & 0.511 \\
\hline T-Time & 3 & 2.89 & 4.00 & 0.024 & 4.26 & 5.39 & 0.005 \\
\hline $\mathrm{E} \times \mathrm{T}$ & 3 & 2.01 & 2.78 & 0.063 & 0.71 & 0.89 & 0.455 \\
\hline Res & 24 & 0.72 & & & 0.79 & & \\
\hline Total & 31 & & & & & & \\
\hline
\end{tabular}

\begin{tabular}{|c|c|c|c|c|c|c|c|}
\hline & \multicolumn{7}{|c|}{ Sagitta friderici } \\
\hline & \multirow[b]{2}{*}{ df } & \multicolumn{3}{|l|}{$\delta^{15} \mathrm{~N}$} & \multicolumn{3}{|l|}{$\delta^{13} \mathrm{C}$} \\
\hline & & MS & $F$ & $P$ & MS & $F$ & $P$ \\
\hline $\begin{array}{l}\text { E-Estuary } \\
\text { T-Time }\end{array}$ & 1 & 1.50 & 1.70 & 0.232 & 0.65 & 1.45 & 0.284 \\
\hline $\mathrm{E} \times \mathrm{T}$ & 6 & 0.88 & & & 0.45 & & \\
\hline $\begin{array}{l}\text { Res } \\
\text { Total }\end{array}$ & 7 & & & & & & \\
\hline
\end{tabular}

\begin{tabular}{|c|c|c|c|c|c|c|c|}
\hline & \multicolumn{7}{|c|}{ Zoea (decapod) } \\
\hline & \multirow[b]{2}{*}{ df } & \multicolumn{3}{|l|}{$\delta^{15} \mathrm{~N}$} & \multicolumn{3}{|l|}{$\delta^{13} \mathrm{C}$} \\
\hline & & MS & $F$ & $P$ & MS & $F$ & $P$ \\
\hline E-Estuary & 1 & 0.81 & 1.38 & 0.258 & 0.43 & 0.27 & 0.627 \\
\hline T-Time & 1 & 2.24 & 3.83 & 0.066 & 0.66 & 0.42 & 0.535 \\
\hline $\mathrm{Ex} \mathrm{T}$ & 1 & 0.18 & 0.30 & 0.596 & 0.09 & 0.06 & 0.818 \\
\hline Res & 12 & 0.59 & & & 1.60 & & \\
\hline Total & 15 & & & & & & \\
\hline
\end{tabular}

\begin{tabular}{|c|c|c|c|c|c|c|c|}
\hline & \multicolumn{7}{|c|}{ POM } \\
\hline & \multirow[b]{2}{*}{ df } & \multicolumn{3}{|l|}{$\delta^{15} \mathrm{~N}$} & \multicolumn{3}{|l|}{$\delta^{13} \mathrm{C}$} \\
\hline & & MS & $F$ & $P$ & MS & F & $P$ \\
\hline E-Estuary & 1 & 4.63 & 51.41 & $<0.001$ & 0.65 & 3.54 & 0.073 \\
\hline T-Time & 3 & 3.10 & 34.39 & $<0.001$ & 2.30 & 12.48 & $<0.001$ \\
\hline $\mathrm{Ex} \mathrm{T}$ & 3 & 0.75 & 8.33 & $<0.001$ & 0.43 & 2.36 & 0.097 \\
\hline Res & 24 & 0.09 & & & 0.18 & & \\
\hline Total & 31 & & & & & & \\
\hline
\end{tabular}

Table 7

Pearson correlation analysis of zooplankton stable nitrogen and carbon isotope values for all groups/species and environmental factors, and for the consumer Pomatoschistus microps larvae and the food sources. Only statistically significant $P$-values $(<0.05)$ are shown, which indicate statistically significant non-zero correlations at the $95.0 \%$ confidence level.

\begin{tabular}{|c|c|c|c|c|}
\hline & P. microps & Ammonium & Nitrate & Salinity \\
\hline \multicolumn{5}{|l|}{ Minho } \\
\hline Pomatoschistus microps & & $0.866^{* *}$ & & $-0.530 *$ \\
\hline Cladocera & $0.851 * *$ & $0.716^{* *}$ & & $-0.853^{* *}$ \\
\hline Copepoda & $0.884 * *$ & $0.616^{*}$ & & $-0.517^{*}$ \\
\hline Particulate organic matter & $0.697 * *$ & $0.697^{* *}$ & & \\
\hline \multicolumn{5}{|l|}{$\delta^{13} \mathrm{C}$} \\
\hline Pomatoschistus microps & & & & $-0.595^{*}$ \\
\hline Cladocera & $0.597^{*}$ & & & $0.545^{*}$ \\
\hline Copepoda & $0.884 * *$ & & & \\
\hline Mysidacea & $0.697^{* *}$ & & $-0.600^{*}$ & $0.560^{*}$ \\
\hline \multicolumn{4}{|l|}{ Lima } & \\
\hline Pomatoschistus microps & & $0.865^{* *}$ & & $-0.796 * *$ \\
\hline Cirripedia & $0.901 * *$ & $0.650 *$ & & \\
\hline Cladocera & $0.834 * *$ & $0.810^{* *}$ & & $-0.647^{* *}$ \\
\hline Copepoda & $0.885^{* *}$ & $0.787 * *$ & $0.505^{*}$ & $-0.723^{* *}$ \\
\hline Mysidacea & $0.633^{* *}$ & & & $-0.623^{* *}$ \\
\hline Zoea (decapoda) & & & & $-0.592^{*}$ \\
\hline Particulate organic matter & $0.881 * *$ & $0.952^{* *}$ & $0.544^{*}$ & $-0.749 * *$ \\
\hline \multicolumn{5}{|l|}{$\delta^{13} \mathrm{C}$} \\
\hline Pomatoschistus microps & & $-0.539 *$ & & $0.746^{* *}$ \\
\hline Copepoda & $0.612^{*}$ & $-0.687^{* *}$ & & $0.600 *$ \\
\hline Mysidacea & $0.498^{*}$ & $-0.643^{* *}$ & & $0.547^{*}$ \\
\hline
\end{tabular}

** means $p<0.01$.

* means $p<0.05$

great calorific value. Also, the red pigmentation of cladocerans increases their visibility and selectively compared to prey of similar size (Nunn et al., 2012; Robert et al., 2014). During the present study, the chaetognath prey $S$. friderici was available only in November 2012, in both estuaries, with a relatively important contribution to the diet of goby larvae in Lima, perhaps reflecting a reproductive period of this species. Temporal differences in the relative proportion of prey items ingested, between Minho and Lima, were particularly evident in November 2012 and February 2013, when the available food resources became reduced. Low availability of other zooplanktonic prey organisms in colder months may have led $P$. microps larvae to greatly exploit copepods, particularly in Lima.

\subsection{Anthropogenic input of $N$}

Physicochemical characterisation showed relevant temporal differences in the water columns between the two estuaries. The influence of salinity was higher in Lima, with lower values in November 2012 and February 2013, where the main factors contributing to changes in the river flow are the direct rainfall on the water surface and the runoff of rainfall over the surrounding drainage basins (Vieira et al., 2015). In Minho, the salinity values were near zero in colder months and revealed 
Table 8

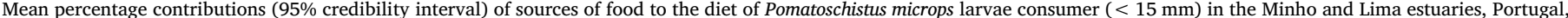
across the sampling dates.

\begin{tabular}{|c|c|c|c|c|c|c|c|c|c|c|c|c|c|c|c|c|}
\hline \multirow{3}{*}{$\begin{array}{l}\text { Sources of food } \\
\text { Cir }\end{array}$} & \multicolumn{8}{|c|}{ Minho } & \multicolumn{8}{|c|}{ Lima } \\
\hline & \multicolumn{2}{|c|}{ Jul 2012} & \multicolumn{2}{|c|}{ Nov 2012} & \multicolumn{2}{|c|}{ Feb 2013} & \multicolumn{2}{|c|}{ Jun 2013} & \multicolumn{2}{|c|}{ Jul 2012} & \multicolumn{2}{|c|}{ Nov 2012} & \multicolumn{2}{|c|}{ Feb 2013} & \multicolumn{2}{|c|}{ Jun 2013} \\
\hline & 13 & $(0-31)$ & & & & & 7 & $(0-18)$ & 8 & $(0-21)$ & & & & & 9 & $(0-22)$ \\
\hline Cla & 5 & $(0-14)$ & & & 21 & $(0-44)$ & 7 & $(0-20)$ & 12 & $(0-29)$ & & & 13 & $(0-37)$ & 9 & $(0-22)$ \\
\hline Cop & 41 & $(16-66)$ & 34 & $(5-62)$ & 41 & $(6-74)$ & 35 & $(3-51)$ & 46 & $(20-61)$ & 48 & $(25-75)$ & 60 & $(20-97)$ & 37 & $(12-65)$ \\
\hline Mys & 19 & $(0-38)$ & 21 & $(0-41)$ & 28 & $(0-31)$ & 16 & $(0-32)$ & 17 & $(0-38)$ & & & 17 & $(0-44)$ & 18 & $(4-35)$ \\
\hline Sag & & & 18 & $(1-33)$ & & & & & & & 40 & $(7-68)$ & & & & \\
\hline Zoea & 17 & $(0-34)$ & & & & & 29 & $(11-60)$ & 14 & $(0-31)$ & & & & & 23 & $(5-40)$ \\
\hline POM & 5 & $(0-10)$ & 27 & $(9-44)$ & 10 & $(0-20)$ & 6 & $(0-14)$ & 3 & $(0-8)$ & 12 & $(0-23)$ & 10 & $(0-30)$ & 4 & $(0-11)$ \\
\hline
\end{tabular}

that this system is highly dependent on river freshwater inputs, in good accordance with previous studies that reported a strong influence of river discharges on Minho hydrologic characteristics (Reis et al., 2009; Vieira et al., 2015), mainly during high precipitation periods (Fatela et al., 2014). The marked drop in salinity in colder months coincided with increases in ammonium and nitrate concentrations, in both estuaries, with a greater expression in Lima in February 2013. Such increases may have been due to a flush effect of the rains in washing accumulated chemicals from surrounding agricultural areas, and domestic and industrial wastes into the estuaries. By comparing the ammonium concentration in the water column in February 2013 to the values reported in other studies to the Lima system in earlier periods of time (e.g. Saraiva et al., 2007; Ramos et al., 2015; Vieira et al., 2015), we found the most enriched concentrations recorded so far, with maximum values around $5.7 \mathrm{mg} \mathrm{L}^{-1}$. These observations show a possible decrease of water quality, and should be taken as a warning for future environmental problems before they become acute. Water column concentrations of chlorophyll $a$ [assumed as a proxy of phytoplankton biomass (Carmo et al., 2013)] increased markedly in warmer months, with a greater expression in Lima. It is reasonable to suppose that these increases resulted from blooms that were stimulated by nitrogen inputs into the estuaries during the rainy season which preceded our sampling.

The dual-stable isotope plots showed that the plankton food webs were similar between estuaries, although there were differences in the plankton isotopic ratios of carbon and nitrogen between estuaries and among sampling dates. The lack of differences in the $\delta^{15} \mathrm{~N}$ and the very narrow range of the $\delta^{13} \mathrm{C}$ of zooplanktivorous fish for the two size classes suggest a similar use of the food sources available. A general depletion in $\delta^{13} \mathrm{C}$ values of the zooplankton community in November 2012 and February 2013, in both estuarine systems, appears to be correlated with a decrease in the salinity values. The depleted carbon signatures found in Minho, could be due to a great contribution of terrestrial organic matter to this system from freshwater discharges, particularly in November 2012 and February 2013 (salinity concentrations near zero), since several studies have shown that terrestrial plants have the most depleted $\delta^{13} \mathrm{C}$ signatures, around $-26 \%$ (e.g. Vizzini and Mazzola, 2003; Baeta et al., 2009b). Concomitantly, enriched $\delta^{13} \mathrm{C}$ ratios were found in Lima in July 2012 and June 2013, periods with higher salinities and influenced to a greater degree by marine sources, which tend to have higher $\delta^{13} \mathrm{C}$ values.

The most important finding in our study is that zooplanktivorous fish isotopic signatures reflect anthropogenic activity in estuarine ecosystems, and function as an exposure indicator of nitrogen pollution. Changes in the $\delta^{15} \mathrm{~N}$ of the overall zooplankton community, except for hyperbenthic groups (mysids and zoea), were strongly correlated with the ammonium concentrations in the water column. $\delta^{15} \mathrm{~N}$ in plankton increased with nitrogen concentration, in both estuaries, reflecting increased inputs of anthropogenic nitrogen. This increase was particularly evident in Lima. It has been assumed that Lima is under higher anthropogenic impact, when compared to Minho, and our results confirm these observations. This study demonstrates that water quality (ammonium, which reflects both nitrogen sources and hydrologic exchange) influences $\delta^{15} \mathrm{~N}$. Ammonium can come from domestic, industrial or agricultural pollution, and highly significant correlations between fish $\delta^{15} \mathrm{~N}$ and ammonium imply a direct response to anthropogenic inputs of nitrogen. Our findings are in good agreement with Hoffman et al. (2012), who reported that $\delta^{15} \mathrm{~N}$ in fish larvae is a responsive indicator of watershed sources of anthropogenic nitrogen in coastal receiving water. Inferring, however, which specific nitrogen sources contribute to elevate $\delta^{15} \mathrm{~N}$ is difficult, since these ecosystems contain a variety of different pollution sources that contribute to the nitrogen load to estuarine ecosystems. Since it is difficult to determine the precise contaminant sources of nitrogen pollution, additional studies are needed. Stable isotopes used in conjunction with other techniques, such as, for instance, compound-specific stable isotope analysis (CSIA) of natural isotopic abundance may greatly enhance the evaluation of sources and transformation processes of pollutants, relevant to environmental decision makers (Elsner and Imfeld, 2016).

\section{Acknowledgements}

This study was financially supported by Portuguese and European Regional Development funds through the Portuguese Foundation for the Science and Technology (FCT) and the Operational Competitiveness Programme (COMPETE) under the project "SIGNAL" (PTDC/AACAMB/110331/2009; FCOMP-01-0124-FEDER-013876). The work was also supported in the scope of the MARE (Marine and Environmental Sciences Centre) strategic plan (ID/MAR/04292/2013). Alexandra Baeta and Luís R. Vieira had postdoc fellowships from FCT (SFRH/BPD/ 95160/2013 and SFRH/BPD/47407/2008, respectively) supported by the European Social Fund and national funds from the "Ministério da Educação e Ciência (POPH e QREN e Tipologia 4.1)" of Portugal. Ana Lírio had a Grant in the scope of the SIGNAL project (ECOTOXLAB/ PTDC/AAC-AMB/110331/2009/BIC/2012-036). Special thanks are addressed to Dr. Filipa Bessa and Dr. Verónica Ferreira for data analysis, José Sousa and Eduardo Martins for the valuable field work assistance.

\section{References}

Adams, S.M., 2005. Using multiple response bioindicators to assess the health of estuarine ecosystems: An operational framework. In: Bortone, S.A. (Ed.), Estuarine Indicators. CRC Press, Boca Raton, pp. 5-18.

Aminot, A., Rey, F., 2001. Chlorophyll a: determination by spectroscopic methods. ICES Tech. Mar. Environ. Sci. 30, 1-18.

Anderson, M.J., 2001. Permutation tests for univariate or multivariate analysis of variance and regression. Can. J. Fish Aquat. Sci. 58, 626-639.

Azevedo, I., Ramos, S., Mucha, A.P., Bordalo, A.A., 2013. Applicability of ecological assessment tools for management decision-making: a case study from the Lima estuary (NW Portugal). Ocean Coast. Manag. 72, 54-63.

Baeta, A., Valiela, I., Rossi, F., Pinto, R., Richard, P., Niquil, N., Marques, J.C., 2009a. Eutrophication and trophic structure in response to the presence of the eelgrass Zostera noltii. Mar. Biol. 156, 2107-2120.

Baeta, A., Pinto, R., Valiela, I., Richard, P., Niquil, N., Marques, J.C., 2009b. $\delta^{15} \mathrm{~N}$ and $\delta^{13} \mathrm{C}$ in the Mondego estuary food web: seasonal variation in producers and 
consumers. Mar. Environ. Res, 67, 109-116.

Bannon, R.O., Roman, C.T., 2008. Using stable isotope to monitor anthropogenic nitrogen inputs to estuaries. Ecol. Appl. 18, 22-30.

Carmo, V., Santos, M., Menezes, G.M., Loureiro, C.M., Lambardi, P., Martins, A., 2013. Variability of zooplankton communities at Condor seamount and surrounding areas, Azores (NE Atlantic). Deep Sea Res. Part II Top. Stud. Oceanogr. 98 (Part A), 63-74.

Caut, S., Elena Angulo, E., Courchamp, F., 2009. Variation in discrimination factors $\left(\Delta^{15} \mathrm{~N}\right.$ and $\Delta^{13} \mathrm{C}$ ): the effect of diet isotopic values and applications for diet reconstruction. J. Appl. Ecol. 46, 443-453.

Cloern, J.E., 2001. Our evolving conceptual model of the coastal eutrophication problem. Mar. Ecol. Prog. Ser. 210, 223-253.

Cole, M.L., Kroeger, K.D., McClelland, J.W., Valiela, I., 2006. Efects of watershed land use on nitrogen concentrations and $\delta^{15} \mathrm{~N}$ nitrogen on groundwater. Biogeochemistry 77, 199-215.

Costa-Dias, S., Sousa, R., Antunes, C., 2010. Ecological quality assessment of the lower Lima Estuary. Mar. Poll. Bull. 61, 234-239.

Cummings, D.O., Buhl, J., Lee, R.W., Simpson, S.J., Holmes, S.P., 2012. Estimating niche width using stable isotopes in the face of habitat variability: a modelling case study in the marine environment. PLoS One 7 (8), e40539.

DeNiro, M.J., Epstein, S., 1978. Influence of diet on the distribution of carbon isotopes in animals. Geochim. Cosmochim. Acta 42, 495-506.

DeNiro, M.J., Epstein, S., 1981. Influence of diet on the distribution of nitrogen isotopes in animals. Geochim. Cosmochim. Acta 45, 341-351.

Dolbeth, M., Martinho, F., Leitão, R., Cabral, H., Pardal, M.A., 2007. Strategies of Pomatoschistus minutus and Pomatoschistus microps to cope with environmental instability. Estuar. Coast. Shelf Sci. 74, 263-273.

Dolbeth, M., Martinho, F., Viegas, I., Cabral, H., Pardal, M.A., 2008. Estuarine production of resident and nursery fish species: conditioning by drought events? Estuar. Coast. Shelf Sci. 78, 51-60.

Eggers, T., Jones, T.H., 2000. You are what you eat...or are you? Trends Ecol. Evol. 15, 265-266.

Elsner, M., Imfeld, G.I., 2016. Compound-specific isotope analysis (CSIA) of micropollutants in the environment - current developments and future challenges. Curr. Opin. Biotechnol. 41, 60-72.

Fatela, F., Moreno, J., Leorri, E., Corbett, R., 2014. High marsh foraminiferal assemblages' response to intra-decadal and multi-decadal precipitation variability, between 1934 and 2010 (Minho, NW Portugal). J. Sea Res. 93, 118-132.

Ferreira, J.G., Abreu, P.F., Bettencourt, A.M., Bricker, S.B., Marques, J.C., Melo, J.J., Newton, A., Nobre, A., Patrício, J., Rocha, F., Rodrigues, R., Salas, F., Silva, M.C., Simas, T., Soares, C.V., Stacey, P.E., Vale, C., de Wit, M., Wolff, W., 2005. Monitoring Plan for Portuguese Coastal Waters. Water Quality and Ecology. Development of Guidelines for the Applications of the European Union Water Framework Directive $141 \mathrm{p}$.

Freitas, V., Costa-Dias, S., Campos, J., Bio, A., Santos, P., Antunes, C., 2009. Patterns in abundance and distribution of juvenile flounder, Platichthys flesus in Minho estuary (NW Iberian Peninsula). Aquat. Ecol. 43, 1143-1153.

Fry, B., Sherr, E.B., 1984. $\delta^{13} \mathrm{C}$ measurements as indicators of carbon in marine and freshwater ecosystems. Contrib. Mar. Sci. 27, 13-47.

Graniero, L.E., Grossman, E.L., Aaron O'Dea, A., 2016. Stable isotopes in bivalves as indicators of nutrient source in coastal waters in the Bocas del Toro Archipelago, Panama. PeerJ 20.

Guimarães, L., Gravato, C., Santos, J., Monteiro, L.S., Guilhermino, L., 2009. Yellow eel (Anguilla anguilla) development in NW Portuguese estuaries with different contamination levels. Ecotoxicol. Lond. Engl. 18, 385-402.

Guimarães, L., Medina, M.H., Guilhermino, L., 2012. Health status of Pomatoschistus microps populations in relation to pollution and natural stressors: implications for ecological risk assessment. Biomarkers Biochem. Indic. Expo. Response Susceptibility Chem. 17, 62-77.

Hoffman, J.C., Kelly, J.R., Peterson, G.S., Cotter, A.M., Starry, M.A., Sierszen, M.E., 2012. Using $\delta^{15} \mathrm{~N}$ in fish larvae as an indicator of watershed sources of anthropogenic nitrogen: response at multiple spatial scales. Estuar. Coasts. 35, 1453-1467.

Jackson, J., Lenz, P.H., 2016. Predator-prey interactions in the plankton: larval fish feeding on evasive copepods. Sci. Rep. 6, 33585 (11pp).

Layman, C.A., Araujo, M.S., Boucek, R., Hammerschlag-Peyer, C.M., Harrison, E., Jud, Z.R., et al., 2012. Applying stable isotopes to examine food-web structure: an overview of analytical tools. Biol. Rev. 87, 545-562.

Lazzaro, X., 1987. A review of planktivorous fishes: their evolution feeding behaviours, selectivities, and impacts. Hydrobiologia 146, 97-167.

Leitão, R., Martinho, F., Neto, J.M., Cabral, H., Marques, J.C., Pardal, M.A., 2006. Feeding ecology, population structure and distribution of Pomatoschistus microps (Krøyer 1838) and Pomatoschistus minutus (Pallas, 1770) in a temperate estuary, Portugal. Estuar. Coast. Shelf Sci. 66, 231-239.

Levin, L.A., Boesch, D.F., Covich, A., Dahm, C., Erséus, C., Ewel, K.C., Kneib, R.T., Moldenke, A., Palmer, M.A., Snelgrove, P., Strayer, D., Weslawski, J.M., 2001. The function of marine critical transition zone and the importance of sediment biodiversity. Ecosystems 4, 430-451.

Llopiz, J.K., 2013. Latitudinal and taxonomic patterns in the feeding ecologies of fish larvae: a literature synthesis. J. Mar. Syst. 109-110, 69-77.

Lotze, H.K., Lenihan, H.S., Bourque, B.J., Bradbury, R.H., Cooke, R.G., Kay, M.C., Kidwell,
S.M., Kirby, M.X., Peterson, C.H., Jackson, J.B.C., 2006. Depletion, degradation, and recovery potential of estuaries and coastal seas. Science 312, 1806-1809.

MacArthur, R.H., Pianka, E.R., 1966. On optimal use of a patchy environment. Amer Nat. 100, 603-609.

Maes, J., Brabandere, L., Ollevier, F., Mees, J., 2003. The diet and consumption of dominant fish species in the upper Scheldt estuary, Belgium. J. Mar. Biol. Ass. U.K. $83,603-612$.

Nikinmaa, M., 2014. An Introduction to Aquatic Toxicology. Chapter 12. pp. 147-155.

Nunn, A.D., Tewson, L.H., Cowx, I.G., 2012. The foraging ecology of larval and juvenile fishes. Rev. Fish Biol. Fish. 22, 377-408.

Paerl, H.W., Dyble, J., Moisander, P.H., Noble, R.T., Piehler, M.F., Pinckney, J.L., Steppe, T.F., Twomey, L., Valdes, L.M., 2003a. Microbial indicators of aquatic ecosystem change: current applications to eutrophication studies. Fems Microbiol. Ecol. 46, 233-246.

Paerl, H.W., Valdes, L.M., Pinckney, J.L., Piehler, M.F., Dyble, J., Moisander, P.H., 2003b Phytoplankton photopigments as indicators of estuarine and coastal eutrophication. Bioscience 53, 953-964.

Parmanne, R., Lindstrom, K., 2003. Annual variation in gobiid larval density in the northern Baltic Sea. J. Fish Biol. 62, 413-426.

Parnell, A.C., Inger, R., Bearhop, S., Jackson, A.L., 2010. Source portioning using stable isotopes: coping with too much variation. PLoS One 5, 3.

Pasquaud, S., David, V., Lobry, J., Girardin, M., Sautour, B., Elie, P., 2010. Exploitation of trophic resources by fish under stressful estuarine conditions. Mar. Ecol. Prog. Ser. 400, 207-219.

Peterson, B.J., Fry, B., 1987. Stable isotopes in ecosystems studies. Annu. Rev. Ecol. Syst. 18, 293-320.

Pinto, R., Martins, F.C., 2013. The portuguese national strategy for Integrated coastal zone management as a spatial planning instrument to climate change adaptation in the minho river estuary (Portugal NW-coastal zone). Environ. Sci. Policy 33, 76-96.

Post, D.M., 2002. Using stable isotopes to estimate trophic position: models, methods, and assumptions. Ecology 83, 703-718.

Pruell, R.J., Taplin, B.K., 2015. Carbon and nitrogen isotope ratios of juvenile winter flounder as indicators of inputs to estuarine systems. Mar. Pollut. Bull. 101, 624-631.

Ramos, S., Ré, P., Bordalo, A.A., 2009. Environmental control on early life stages of flatfishes in the Lima estuary (NW Portugal). Estuar Coast Shelf Sci. 83, 252-264.

Ramos, S., Cabral, H., Elliott, M., 2015. Do fish larvae have advantages over adults and other components for assessing estuarine ecological quality? Ecol. Ind. 55, 74-85.

Reis, J.L., Martinho, A.S., Pires-Silva, A.A., Silva, A.J., 2009. Assessing the influence of the river discharge on the Minho estuary tidal regime. J. Coast. Res. SI56, 1405-1409.

Robert, D., Murphy, H.M., Jenkins, G.P., Fortier, L., 2014. Poor taxonomical knowledge of larval fish prey preference is impeding our ability to assess the existence of a critical period driving year-class strength. J. Mar. Sci. 71, 2042-2052.

Salgado, J.P., Cabral, H.N., Costa, M.J., 2004. Feeding ecology of the gobies Pomatoschistus minutus (Pallas, 1770) and Pomatoschistus microps (Krøyer 1838) in the upper Tagus estuary, Portugal. Sci. Mar. 68, 425-434.

Saraiva, S., Pina, P., Martins, F., Santos, M., Braunschweig, F., Neves, R., 2007. Modelling the influence of nutrient loads on Portuguese Estuaries. Hydrobiologia 587, 5-18.

Savage, C., 2009. Development of Bioindicators for the Assimilation of Terrestria Nutrient Inputs in Coastal Ecosystems as a Tool for Watershed Management. New Zealand Aquatic Environment and Biodiversity Report. No. 30. 35 p.

Sousa, R., Guilhermino, L., Antunes, C., 2005. Molluscan fauna in the freshwater tidal area of the River Minho estuary, NW of Iberian Peninsula. Ann. Limnol. - Int. J. Limnol. 41, 141-147.

Sousa, R., Dias, S., Antunes, C., 2006. Spatial subtidal macrobenthic distribution in relation to abiotic conditions in the Lima estuary, NW of Portugal. Hydrobiologia 559, $135-148$.

Sousa, M.C., Mendes, R., Alvarez, I., Vaz, N., Gomez-Gesteira, M., Dias, J.M., 2014 Unusual circulation patterns of the rias baixas induced by minho freshwater intrusion (NW of the iberian peninsula). PLoS One 9, e112587.

Strydom, N.A., Sutherland, K., Wooldridge, T.H., 2014. Diet and prey selection in latestage larvae of five species of fish in a temperate estuarine nursery. Afr. J. Mar. Sci. $36,85-98$.

Thiel, R., Mehner, T., Kopcke, B., Kafemann, R., 1996. Diet niche relationships among early life stages of fish in German estuaries. Mar. Freshw. Res. 47, 123-136.

Van Dover, C.L., Grassle, J.F., Fry, B., Garritt, R.H., Starczak, V.R., 1992. Stable isotope evidence for entry of sewage-derived organic material into a deep-sea food web. Nature 360, 153-156.

Vieira, L.R., Guilhermino, L., Morgado, F., 2015. Zooplankton structure and dynamics in two estuaries from the Atlantic coast in relation to multi-stressors exposure. Estuar. Coast. Shelf Sci. 167, 347-367.

Vizzini, S., Mazzola, A., 2003. Seasonal variations in the stable carbon and nitrogen isotope ratios $(13 \mathrm{C} / 12 \mathrm{C}$ and $15 \mathrm{~N} / 14 \mathrm{~N})$ of primary producers and consumers in a western Mediterranean coastal lagoon. Mar. Biol. 142, 1009-1018.

Wada, E.H., Mizutani, H., Minagawa, M., 1991. The use of stable isotopes for food web analysis. Crit. Rev. Food Sci. Nutr. 30, 361-371.

West, J.B., Bowen, G.J., Cerling, T.E., Ehleringer, J.R., 2006. Stable isotopes as one of nature's ecological recorders. Trends Ecol. Evol. 21, 408-414. 